\title{
Impression Management News Anchor dalam Membawakan Berita
}

\author{
Nuril Lutfiah Saleh ${ }^{*}$ \\ Fakultas Ilmu Komunikasi, Universitas Islam Bandung, Indonesia. \\ *nurlutsal@gmail.com
}

\begin{abstract}
A news anchor is someone who presents some information in a news television program. The appearance of a news anchor which looks smart, neat, and prestigious is one of the factors why Indonesian viewers still getting information from television. However, news anchors are not always looking like they do on the TV. Everyone has their front stage which consists of a personal front (anything within them) and expressive equipment (supporting tools for their role), also the back stage which consists of anything hidden. In this case, a news anchor might be having an opposite character shown on or off-camera. This research aims to discover the front stage and the back stage of a news anchor from TVRI Jawa Barat, Mehdi Hairi Yazdi. This research used the qualitative method with Goffman's dramaturgy approach. In this research also, data were collected by field research (interviews, observation, and documents) and literature research. From this research, it is shown that: 1) In the front stage, Mehdi wants to be known as elegant, charismatic, yet still suits his young age through his appearance, manner, and interaction. Mehdi also obeys the rule in the office, yet it's still conditional to make ease on him. 2) In the back stage, Mehdi prioritizes the technical and news source preparation before on-air that shows he's a planning person, and also, Mehdi shows the difference in appearance and manner as well as his true self although he still can suit the situation he is in to.
\end{abstract}

Keywords: Dramaturgy, Impression Management, News Anchor.

Abstrak. Pembawa acara berita atau news anchor merupakan seseorang yang menyajikan serangkaian informasi dalam sebuah program televisi. Kehadiran news anchor pun menjadi salah satu faktor masyarakat Indonesia masih menonton berita di televisi karena news anchor yang menampilkan kesan cerdas, rapi, dan berwibawa saat membawakan program berita. Namun, tidak selamanya seorang news anchor berpenampilan dan berperilaku layaknya ketika membawakan berita di layar kaca, bahkan dalam kegiatan sehari-hari. Setiap orang memiliki panggung depan (front stage) yang terdiri dari personal front (segala yang melekat di dirinya) dan expressive equipment (alat-alat yang mendukung perannya), serta panggung belakang (back stage) yang di dalamnya terdapat hal-hal yang tersembunyi. Dalam hal ini, news anchor bisa jadi memiliki karakter yang bertolak belakang antara di depan dan di belakang kamera. Penelitian ini bertujuan untuk mengetahui panggung depan dan panggung belakang dari news anchor TVRI Jawa Barat yakni Mehdi Hairi Yazdi. Penelitian ini menggunakan metode kualitatif dengan pendekatan dramaturgi Goffman. Dalam penelitian ini, penulis mengambil data melalui teknik lapangan (wawancara, observasi, dan studi dokumentasi) dan teknik literatur. Hasil dari penelitian ini antara lain: 1) Dalam front stage, Mehdi ingin menunjukkan dirinya sebagai news anchor yang elegan, berkharisma, tetapi sesuai dengan usianya yang masih muda kepada pemirsa melalui upaya yang dilakukan dari segi penampilan, sikap dan perilaku, dan interaksi. Mehdi juga merupakan orang yang menaati peraturan atau ketentuan dari kantornya. 2) Dalam back stage, Mehdi lebih mengutamakan persiapan teknis dan materi sebelum siaran yang menunjukkan dia sebagai seorang yang terstruktur, dan dalam back stage pula Mehdi menunjukkan perbedaan penampilan dan sifat serta menunjukkan jati diri dia yang sebenarnya walaupun masih bisa disesuaikan dengan situasi dan agenda yang diikuti.

Kata Kunci: Dramaturgi, Impression Management, News Anchor. 


\section{A. Pendahuluan}

Pembawa acara berita atau yang dikenal juga dengan sebutan news anchor merupakan orang yang menyajikan berita untuk sebuah program berita di televisi. Biasanya dalam program tersebut dibawakan oleh satu hingga dua orang news anchor, bahkan lebih jika dalam acara tertentu. News anchor juga dapat memiliki program beritanya sendiri, yang umumnya ditunjukkan dengan penyematan namanya setelah nama programnya, misal "Insight with Desi Anwar" di CNN Indonesia, atau "Rosi" dan "Aiman" di Kompas TV.

Ketika mendengar kata news anchor, masyarakat mungkin akan membayangkan seseorang dengan penampilan rapi, memiliki kharisma, dan menunjukkan sikap formal (seperti berdiri/duduk dengan tegak dan berbicara formal). Atau masyarakat memiliki pandangan bahwa seorang news anchor merupakan figur yang cerdas dan menguasai apa yang ia sampaikan dalam layar kaca. Maka tak heran profesi ini menjadi primadona untuk sebagian besar orang.

Berbeda dengan news reader yang hanya membacakan berita, news anchor dituntut memliki kemampuan untuk berimprovisasi atau bahkan memberi pandangan terhadap berita karena pada dasarnya news anchor masih sama seperti jurnalis, tetapi bedanya hanya ditempatkan di studio bukan di lapangan.

Seorang news anchor memiliki tuntutan agar mampu menampilkan yang terbaik kepada audiens. Karena selain isi dari berita, pembawaan news anchor juga turut mempengaruhi persepsi audiens terhadap berita yang disampaikan. Kehadiran news anchor juga mempengaruhi kredibilitas media dan kepercayaan masyarakat terhadap media. Itulah sebabnya news anchor harus menjaga sikap dan penampilan sebagai seorang yang berwibawa.

Karena hal inilah, masih banyak masyarakat Indonesia yang menjadikan televisi sebagai sumber utama mereka untuk mendapatkan informasi. Berdasarkan penelitian dari GlobalWebIndex pada 2020 yang dilansir dari Databoks, masyarakat Asia Tenggara (termasuk Indonesia) lebih lama menonton siaran televisi ketimbang layanan internet video streaming. Di Indonesia sendiri, masyarakatnya menonton televisi selama 1 jam 50 menit dibandingkan menonton video streaming yang hanya 60 menit (Lidwina, 2021, diakses 15 Mei 2021).

Ini juga dibuktikan dengan penelitian yang dilakukan pada 2014 berjudul "Faktor-faktor Pendorong Orang Menonton Program Berita "Liputan 6" di SCTV" yang dilakukan oleh Nanda Agus Budiono dari Universitas Atma Jaya Yogyakarta, yang bertujuan untuk mengetahui faktor yang mempengaruhi masyarakat untuk menonton tayangan berita "Liputan 6" SCTV. Penelitian yang dilakukan secara kuantitatif dengan mengambil responden masyarakat Kampung Sudagaran di Tegalrejo, Yogyakarta tersebut memilih faktor penyiar berita sebagal salah satu variabel. Dalam penelitiannya, faktor penyiar berita mendapat persentase sekitar 26,5\%, di samping faktor fungsi media di angka $23,8 \%$, faktor visual berita di angka $26,5 \%$, dan ketiganya di angka $64,5 \%(2)$.

Televisi memiliki kelebihan yakni dapat menyampaikan peristiwa dalam bentuk gambar dan suara secara sekaligus serta mampu menjangkau audiens yang lebih luas juga beragam. Media televisi pun mampu mempengaruhi pandangan masyarakat akan realitas. Salah satu asumsi teori kultivasi Gerbner menyatakan bahwa penonton berat (heavy viewers) cenderung mengandalkan televisi sebagai sumber informasi mereka (3).

Televisi yang merupakan media audiovisual memberikan informasi kepada masyarakat berupa program berita. Beberapa program berita di Indonesia sudah menjadi ikon tersendiri semisal "Seputar Indonesia", "Liputan 6", atau "Dunia dalam Berita". Tayangan berita yang ikonik tersebut tentu tidak terlepas dari peran seorang news anchor yang menjadi garis depan karena tampil langsung di depan kamera.

Di Indonesia sendiri ada beragam stasiun televisi, baik itu yang merupakan milik pemerintah maupun yang dikelola swasta. Salah satu yang masih bertahan hingga sekarang adalah Televisi Republik Indonesia atau yang lebih dikenal dengan TVRI, yang juga merupakan Lembaga Penyiaran Publik (LPP) berdasarkan Undang-undang No. 32 Tahun 2002 tentang Penyiaran. Program berita TVRI seperti "Dunia dalam Berita" menjadi ikonik, bahkan setelah hadirnya stasiun televisi swasta pada dekade 1990-an. Jika ditanya siapa news anchor yang paling diingat dalam program berita tersebut, masyarakat kemungkinan akan menjawab Yan Partawijaya atau Anita Rachman karena ciri khas yang mereka miliki masing-masing. 
Tidak hanya terbatas pada stasiun televisi nasional saja, peran penting news anchor juga berlaku di stasiun televisi lokal atau biro daerah. Salah satunya yang masih ditonton masyarakat adalah TVRI Jawa Barat. Stasiun yang berdiri pada 11 Maret 1987 dengan nama awal TVRI Stasiun Bandung tersebut dapat menjangkau seluruh wilayah Jawa Barat dengan bantuan belasan stasuin pemancar yang tersebar di setiap daerah. TVRI Jawa Barat memiliki program berita harian yakni Jawa Barat Hari Ini dan Kalawarta, yang tentu saja membutuhkan peran seorang news anchor untuk menyampaikan berita kepada audiens.

Salah satu news anchor yang dimiliki TVRI Jawa Barat adalah Mehdi Hairi Yazdi yang sudah merintis karirnya sejak masih di bangku kuliah semester tiga pada Oktober 2019. Berdasarkan obrolan sekaligus prariset yang dilakukan penulis, Mehdi bercerita awal karirnya sebagai news anchor yang berawal dari hal tidak terduga walaupun menjadi news anchor adalah impiannya sejak kecil.

Berdasarkan pengamatan penulis saat prariset, Mehdi memang tampil cukup rapih untuk ukuran gaya kasual. Ketika berbincang pun penulis memandang Mehdi sudah mulai memiliki karakter-karakter yang dimiliki news anchor dilihat dari gaya berbicara dan pemilihan diksi walaupun memang tidak sepenuhnya dia terapkan. Namun, itu bukan berarti menjadi penliaian final penulis yang mutlak.

Tidak selamanya seorang news anchor tampak dan berpenampilan seperti apa yang ia tunjukkan di televisi. Seperti manusia pada umumnya, ia bisa saja bersikap bebas dan bertolak belakang dari apa yang biasanya ditampakkan kepada audiens. Fenomena seperti ini terdapat dalam kajian komunikasi berupa teori dramaturgi.

Teori yang dipopulerkan oleh Erving Goffman ini mengatakan bahwa kehidupan manusia digambarkan seperti sebuah panggung teater. Secara garis besar, panggung ini dibagi menjadi wilayah depan (front stage) dan wilayah belakang (back stage). Wilayah depan merujuk pada gaya formal yang ditampilkan di khalayak umum layaknya sedang berperan dalam sebuah sandiwara, sedangkan wilayah belakang merujuk pada tempat ia mempersiapkan diri untuk bermain peran di atas panggung (4).

Teori dramaturgi juga seringkali dikaitkan dengan impression management atau pengelolaan kesan. Goffman juga berpendapat impression management banyak dilakukan oleh orang yang berprofesi dan dituntut untuk menampilkan image positif. Entah dirasakan atau tidak, banyak individu yang melakukan impression management ketika individu tersebut berinteraksi ataupun bersinggungan dengan khalayak luas (5). Artinya, seorang news anchor berusaha menampilkan yang terbaik dari dirinya dan menyembunyikan yang tidak ingin ia perlihatkan ke masyarakat luas karena profesi ini berhadapan langsung dengan banyak orang meskipun tidak secara tatap muka.

Dari beberapa hal yang sudah penulis jelaskan sebelumnya, penulis dapat menarik poin bahwa untuk menampilkan yang terbaik untuk masyarakat dalam membawakan berita, news anchor melakukan impression management atau pengelolaan kesan melalui pemilahan panggung depan (berupa yang ditampilkan ke masyarakat) dan panggung belakang (berupa kegiatan atau hal-hal yang hanya ia tunjukkan ke teman dekat).

Penulis kemudian menentukan penelitian ini akan berfokus pada, "Bagaimana impression management yang dilakukan oleh news anchor ketika membawakan berita?". Adapun tujuan penelitian ini antara lain sebagai berikut:

1. Mengetahui panggung depan yang tampak dari seorang news anchor dalam membawakan berita.

2. Mengetahui panggung belakang yang tampak dari seorang news anchor dalam kehidupan sehari-hari.

\section{B. Metodologi Penelitian}

Pengelolaan kesan atau impression management merupakan bentuk presentasi diri di mana individu sebagai aktor dalam perannya memproyeksikan dirinya dengan mengelola kesan sesuai yang diinginkan, bertujuan agar pesan tersampaikan dengan baik kepada penonton (6). Sebelum dikelola, kesan tersebut lebih dahulu dibentuk melalui proses stereotyping (menerima pengalaman baru dan disimpan menurut kategori tertentu), implicit personality theory 
(mengkategorikan atau membuat konsep), dan atribusi (menyimpulkan konsep tersebut dari perilaku yang diamati). Kemudian kesan tersebut dikelola dengan melibatkan aspek setting, appearance, dan manner (7).

Pembawa acara berita atau news anchor merupakan orang yang membawakan dan menyiarkan berita di stasiun televisi. Untuk menjadi news anchor yang mumpuni, diperlukan keahlian untuk dapat "terhubung" dengan audiens, keahlian mengolah kata dan wawancara, dan memiliki fisik yang prima serta pengetahuan yang luas (8). Tidak hanya itu saja, menurut RM Hartoko (9), syarat untuk menjadi presenter (termasuk news anchor) yang baik antara lain: penampilan, kecerdasan pikiran, keramahan, dan jenis suara yang tepat.

Penelitian ini menggunakan paradigma konstruktivis yang menjelaskan bahwa sebuah realitas sosial bukan tercipta secara alami, melainkan dari hasil konstruksi. Paradigma ini menjelaskan cara realitas sosial tersebut dikonstruksi (10). Metode yang digunakan dalam penelitian ini adalah kualitatif, yang menurut Bursztyn bertujuan untuk mengembangkan pemahaman mengenai pengalaman manusia, interaksi, dan pola perilaku. Penelitian kualitatif berupaya menjelaskan dan menafsirkan alasan-alasan yang melatarbelakangi perilaku tersebut (11).

Sedangkan untuk pendekatan, penelitian ini menggunakan pendekatan dramaturgi. Dramaturgi merupakan teori yang dikembangkan oleh Erving Goffman yang menekankan konsep diri (self) dan mengibaratkan kehidupan sosial manusia sebagai panggung sandiwara. Artinya, individu yang melakukan interaksi sosial seolah-olah melakukan suatu peran guna menciptakan citra diri di hadapan khalayaknya. Panggung pertunjukan tersebut terbagi menjadi wilayah depan (front stage) yang terdiri atas latar dan apa yang melekat pada individu tersebut dan wilayah belakang (back stage) yang merupakan tempat persiapan individu sebelum memainkan perannya sekaligus tempat individu tersebut dapat seutuhnya menjadi dirinya sendiri (6).

\section{Hasil Penelitian dan Pembahasan}

Bagian ini menjelaskan hasil penelitian yang didapat melalui wawancara mendalam dan observasi lapangan yang dilakukan di TVRI Jawa Barat dan lingkungan lainnya secara kondisional rentang waktu Juni-September 2021, yang ditunjang dengan beberapa dokumentasi seperti arsip TVRI Jawa Barat dan literatur terkait pembahasan penelitian. Kemudian temuan data tersebut diolah guna menjawab pertanyaan penelitian yang akan dipaparkan setelah ini.

Narasumber kunci dalam penelitian ini adalah salah satu dari news anchor TVRI Jawa Barat, yakni Mehdi Hairi Yazdi. Selain berprofesi sebagai news anchor dan reporter, Mehdi juga merupakan mahasiswa angkatan 2018 jurusan Ilmu Komunikasi dari Fakultas Ilmu Komunikasi Universitas Padjadjaran. Prestasi yang dimilikinya cukup banyak, salah satunya adalah menjadi finalis dalam ajang The Next Presenter Liputan 6 yang diselenggarakan SCTV.

Penelitian ini juga melibatkan lima narasumber pendukung yang dipilih berdasarkan hubungan/relasinya dengan Mehdi, seperti teman dekat (Gilang Maulana Pratama dan Dimas Bisma Nararya), rekan sesama news anchor (Alma Syifa Maulidina), koordinator penyiar (Deden Kusnadi), dan penonton (Krisdayanti Intan Sari Mase). Wawancara dengan kelima narasumber tersebut dilakukan secara langsung di TVRI Jawa Barat dan juga secara virtual melalui Zoom, menyesuaikan dengan waktu dan kesempatan masing-masing.

Panggung Depan (Front Stage) yang Tampak dari Seorang News Anchor dalam Membawakan Berita)

Aspek ini dianalisis berdasarkan dua aspek: personal front yang meliputi atribut yang melekat pada dirinya (pakaian, jenis kelamin, sikap, karakter, gaya komunikasi) dan expressive equipment (peralatan/properti untuk menunjang penampilan). Dalam front stage, Mehdi berusaha menampilkan dirinya selayaknya news anchor yang memiliki identitas yang formal dan berwibawa. Mehdi pun berperan "mewakili" lembaganya yakni TVRI Jawa Barat yang dikenal sebagai Lembaga Penyiaran Publik (LPP) tingkat daerah.

Pembahasan dimulai dari menganalisis personal front. Secara garis besar, Mehdi menampilkan dirinya sebagai seseorang yang maskulin dan rapi menyesuaikan program yang 
dia bawakan. Biasanya Mehdi membawakan program berita Jawa Barat Hari Ini dan Kalawarta.

Mehdi mengaku ingin dilihat pemirsa sebagai news anchor yang elegan, memiliki kharisma, tetapi tidak berpenampilan lebih tua dari usianya yang masih 21 tahun. Ini dikarenakan pembawaannya yang serius dan karakter suaranya yang cenderung maskulin, sehingga jika dia berpenampilan tidak sesuai usianya, Mehdi sering kali dikenali pemirsa sebagai "bapak-bapak" alih-alih anak muda.

Dari segi pakaian dan aksesoris yang melekat, Mehdi cenderung tidak ambil pusing karena menurutnya persiapan fisik tergolong sederhana dan sama saja antara satu dengan yang lain. Untuk menghindari kesan yang lebih tua dari usianya tersebut, Mehdi cenderung menggunakan kemeja berwarna terang dan menghindari penggunaan kacamata dalam program Jawa Barat Hari Ini. Sedangkan dalam program Kalawarta, dia menggunakan pakaian pangsi atau beskap Sunda yang warnanya disesuaikan dengan rekan siaran wanitanya. Meskipun tidak terdapat aturan secara tertulis mengenai pakaian news anchor sesuai program yang dibawakan, Mehdi tetap menaatinya dengan beberapa penyesuaian untuk kenyamanan dirinya.

Sikap atau karakter yang Mehdi tunjukkan pun berbeda untuk kedua program tersebut. Program Jawa Barat Hari Ini yang merupakan program berita prime time dibawakan dengan lebih tegas atau formal, berbeda dengan Kalawarta yang dibawakan dengan lebih cair dan santai. Akan tetapi, dalam kedua program tersebut Mehdi berpostur tegap dan siap. Sedangkan untuk gestur tubuh yang ditampilkan biasanya Mehdi menggerakan tangannya dengan alasan memudahkan dirinya menyampaikan isi berita mengingat dirinya seorang yang kinestetik.

Terdapat perbedaan juga pada ekspresi Mehdi saat membawakan program berita, seperti misalnya ekspresi formal dalam Jawa Barat Hari Ini dan lebih banyak senyum dalam Kalawarta. Meskipun demikian, Mehdi tetap tampil ramah kepada pemirsa di kedua program.

Terakhir dari segi interaksi atau gaya komunikasi, Mehdi biasanya menyapa dan menanyakan kabar pemirsanya (di bagian pembuka) dan mengajak untuk taat protokol kesehatan beserta slogannya (di penutup). Untuk menyampaikan berita dengan baik, Mehdi terlebih dahulu menyusun poin-poin dari materi tersebut, serta membedakan intonasi berdasarkan isi beritanya.

Kemudian pembahasan front stage dilanjutkan dengan menganalisis expressive equipment yang Mehdi pakai. Baik dalam program Jawa Barat Hari Ini dan Kalawarta, biasanya di atas meja terdapat naskah yang sudah disiapkan oleh redaksi, kamera, layar LED besar sebagai penanda/cue, teleprompter yang teksnya disiapkan sendiri oleh Mehdi (khusus program Jawa Barat Hari Ini), dan klip on.

Jika dilihat kembali pada syarat-syarat untuk menjadi news anchor yang sesuai dengan kaidah dan dapat diterima pemirsa $(8,9)$, Mehdi bisa dikatakan sudah memenuhi kriteriakriteria, di antaranya: penampilan yang ditunjang dengan karakter yang sesuai, pengalaman yang membuat Mehdi terhubung dengan audiens, kemampuan Mehdi dalam komunikasi verbal (pengolahan kata) dan nonverbal (bahasa tubuh dan intonasi), penguasaaan pengetahuan yang membuat dirinya dapat memahami konteks berita yang disampaikan, dan karakter suara yang sudah matang untuk profesi news anchor.

Berikut ini model atau bagan mengenai front stage Mehdi sebagai news anchor: 


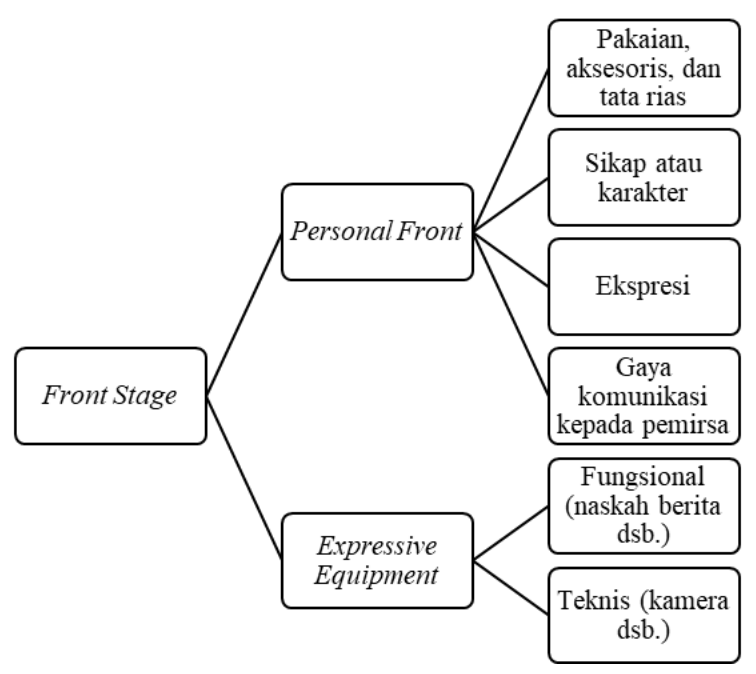

Gambar 1. Bagan/model aspek front stage pada Mehdi sebagai news anchor

Sumber: Olahan peneliti, 2021

\section{Panggung Belakang (Back Stage) yang Tampak dari Seorang News Anchor dalam Kehidupan Sehari-hari}

Wilayah back stage dapat membahas dua hal, yakni persiapan individu sebelum naik ke panggung pertunjukan untuk memainkan perannya, dan wilayah individu tersebut melepas segala atribut yang melekat saat berada di front stage. Dengan kata lain, back stage merupakan wilayah seseorang dapat menunjukkan jati dirinya yang sebenarnya yang tidak pernah dia tunjukkan ketika sedang melakukan peran di front stage.

Untuk bahasan mengenai persiapan sebelum siaran, Mehdi lebih berfokus pada persiapan materi dan teknis siaran ketmbang persiapan penampilan fisiknya. Seperti yang dibahas sebelumnya, persiapan penampilan menurut Mehdi biasanya tidak sulit.

Proses persiapan program Jawa Barat Hari Ini dimulai dari pembuatan naskah dan dubbing, pembuatan lead untuk dimasukkan ke teleprompter, pengecekan teleprompter, lalu dilanjut dengan berganti baju dan merias diri, dan diselesaikan dengan pengecekan teknis sekali lagi. Biasanya Mehdi sudah masuk ke studio 30-45 menit sebelum program dimulai. Untuk Kalawarta, secara teknis persiapannya lebih mudah, tetapi Mehdi butuh usaha lebih dalam hal materi karena program tersebut berbahasa Sunda.

Pembahasan back stage mengenai kehidupan sehari-hari Mehdi di luar profesinya sebagai news anchor pun dibagi ke dalam aspek appearance dan manner untuk memudahkan klasifikasi perbedaannya. Namun, secara keseluruhan Mehdi memang menunjukkan jati diri yang sebenarnya dan tetap bersosialisasi seperti orang kebanyakan. Dia pun tidak membawa karakter atau atribut dari front stage dirinya sebagai news anchor.

Secara penampilan, Mehdi tidak terlalu berpatokan pada gaya fashion tertentu selama dirinya masih merasa nyaman, tetapi dia tetap menyesuaikannya dengan agenda/kegiatan seperti bersama teman dekat atau selain mereka. Sebenarnya, ketika tidak menjadi news anchor, Mehdi tidak pernah mengenakan pomade dan membiarkan rambutnya menutupi dahi.

Aspek manner dalam penelitian ini dibagi lagi ke dalam interaksi sosial secara langsung dan interaksi di media sosial. Dari penelitian yang dilakukan, terdapat perbedaan dalam manner seorang Mehdi ketika sedang berada di front stage dengan di back stage.

Jika Mehdi sebagai news anchor menampilkan dirinya sebagai pribadi yang elegan, berkharisma, dan ramah, tetapi sebenarnya Mehdi merupakan seorang yang introvert. Dia mengaku cenderung pendiam saat berada di lingkungan atau kerumunan yang ramai, sedangkan dia lebih senang jika hanya ada 2-3 orang saja di sekitarnya. Bahkan, Mehdi sesekali menghabiskan waktunya sendirian. Jika sudah merasa dekat dengan seseorang atau sekelompok teman, Mehdi bisa menjadi orang yang senang bercanda dan berbagi cerita.

Saat bersosialisasi bersama orang lain, Mehdi dapat menyesuaikan dan menempatkan JRJMD is licensed under Creative Commons Attribution- 
dirinya sesuai lawan bicara dan situasi sekitarnya. Misalnya, cara komunikasi Mehdi dengan orang kantor akan berbeda dengan teman-teman dan keluarganya seperti perbedaan penggunaan kata ganti "saya-bapak/ibu/akang/teteh", "aku-kamu", dan "urang-maneh".

Mehdi juga merupakan orang yang visioner dan memiliki tujuan jangka panjang dalam hidupnya. Ini dibuktikan dengan kebiasaannya yang membuat rencana yang terstruktur dalam menjalani kesehariannya. Menurut pengakuannya, Mehdi memang sebisa mungkin tidak membuang kesempatan dan peluang sekecil apapun dan melakukan banyak hal untuk mengembangkan potensi dirinya selagi masih bisa.

Sedangkan interaksi yang dilakukan di media sosial, Mehdi lebih cenderung berhatihati dalam mengunggah sesuatu karena merasa dirinya mewakili lembaga. Maka dari itu, Mehdi memperlakukan akunnya sebagai alat personal branding dari sisi profesional dan personalnya. Melalui media sosial juga, Mehdi berinteraksi dengan pemirsa setianya dan sering membalas pesan-pesan yang masuk.

Dari seluruh observasi dan hasil wawancara yang dilakukan untuk mengetahui front stage dan back stage dari Mehdi sebagai news anchor TVRI Jawa Barat, penulis dapat memaknai bahwa Mehdi dapat menyesuaikan dirinya sesuai situasi dan kondisi di sekitarnya. Jika berada di lingkungan kerja, Mehdi akan berpakaian dan berperilaku sesuai aturan/ketentuan yang sudah ditetapkan kantor TVRI Jawa Barat meskipun penulis menemui beberapa news anchor yang lain (khususnya news anchor pria) yang tidak terlalu mengikuti hal tersebut. Dan jika melihat Mehdi yang juga berusaha tampil rapih dengan mengenakan kemeja bahkan pada saat akhir pekan, penulis dapat menilai bahwa Mehdi memang ingin menampilkan dirinya sebagai orang yang tetap menjaga penampilan di mana pun dia berada. Padahal, Mehdi bisa saja berpenampilan seadanya dan lebih santai seperti news anchor pria lainnya karena sebenarnya tidak terlalu dilarang untuk demikian.

Penulis juga mengetahui bahwa Mehdi datang ke kantor hanya saat ada jadwal siaran atau sedang ada agenda dengan pihak TVRI Jawa Barat (misalnya rapat evaluasi atau keperluan lainnya). Mengingat Mehdi masih memiliki kewajiban sebagai mahasiswa dan menjadi news anchor (dan jurnalis) adalah profesi yang cukup menyita waktu, maka dia biasanya bersiaran saat akhir pekan agar alokasi waktu untuk kuliah dan pekerjaannya terbagi dengan baik. Itu artinya, Mehdi tidak melupakan tanggung jawabnya yang lebih wajib, yakni menjalani perannya sebagai mahasiswa yang masih menempuh perkuliahan, dan hal ini bagi penulis merupakan sesuatu yang positif karena tidak semua dapat menyeimbangkan kehidupan perkuliahan dan pekerjaan di saat bersamaan.

Berikut ini model atau bagan mengenai back stage Mehdi di luar profesi sebagai news anchor:

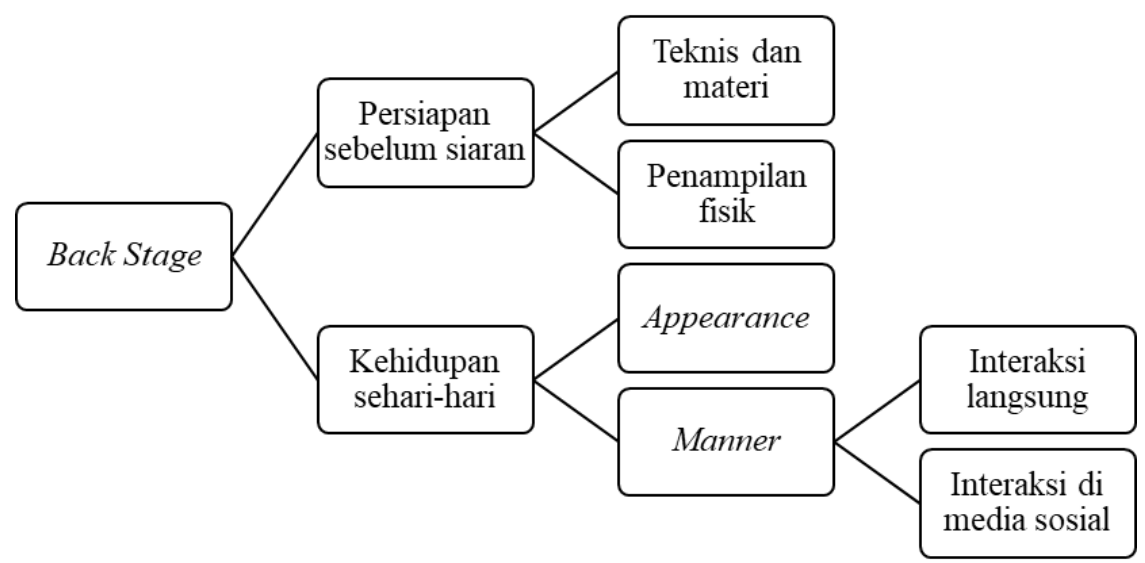

Gambar 2. Bagan/model aspek back stage pada Mehdi di luar profesi news anchor

Sumber: Olahan peneliti, 2021 


\section{Kesimpulan}

Berdasarkan hasil yang didapat untuk menjawab pertanyaan penelitian dalam penelitian yang berjudul "Impression Management News Anchor dalam Membawakan Berita", maka penulis dapat menarik kesimpulan sebagai berikut:

1. Panggung depan atau front stage merupakan tempat di mana seseorang memainkan perannya, yang dalam kehidupan masyarakat adalah profesi. Dalam profesi news anchor, biasanya kesan yang ingin ditampilkan adalah formal, sopan, berkharisma, dan memilki wibawa. Mehdi Hairi Yazdi sebagai news anchor TVRI Jawa Barat ingin menampilkan kesan elegan, berkharisma, tetapi sesuai dengan usianya yang masih relatif muda kepada pemirsa. Upaya yang dia lakukan antara lain memerhatikan penampilan (pakaian dan riasan), sikap dan perilaku (gaya bicara, ekspresi, bahasa tubuh), dan interaksi saat siaran. Serta mengembangkan aspek-aspek penunjang lainnya seperti suara dan sebagainya. Saat menjalani profesinya, Mehdi cenderung menaati peraturan atau ketentuan yang ada di lingkungan kantornya, tetapi masih menyesuaikan dengan karakter dan kenyamanannya.

2. Panggung belakang atau back stage merupakan tempat untuk mempersiapkan diri menuju pentas, juga sebagai wilayah seseorang menjadi dirinya sendiri dan menanggalkan atribut yang melekat saat di front stage. Untuk persiapan menuju siaran, Mehdi lebih mengutamakan aspek teknis dan materi ketimbang penampilan, yang berarti Mehdi memang merupakan orang yang terstruktur dan tertata. Sedangkan untuk kehidupan sehari-hari, terdapat perbedaan yang tampak dari Mehdi mulai dari penampilan, sikap dan perilaku, dan interaksi yang dia lakukan dengan orang-orang di sekitarnya. Dalam back stage juga, tampak jati diri dan karakter Mehdi yang sebenarnya. Meskipun tidak sedang menjalani profesinya, Mehdi terlihat menyesuaikan penampilan dan perilakunya dengan situasi atau agenda yang sedang diikuti.

\section{Acknowledge}

Penulis mengucapkan terima kasih sebanyak-banyaknya kepada pihak-pihak yang mendukung dan membantu kelancaran penulis dalam menyelesaikan penelitian ini:

1. Ibu Dr. Dedeh Fardiah, Dra., M.Si. selaku dosen pembimbing.

2. Seluruh karyawan, anggota redaksi, dan para news anchor TVRI Jawa Barat yang sudah menerima penulis dengan tangan terbuka.

3. Ayah, ibu, dan kedua kakak penulis yang senantiasa memberi dukungan moril.

4. Sahabat dan teman-teman yang senantiasa memberi semangat serta yang sudah membantu semampu mereka.

5. Pihak lainnya yang tidak bisa disebutkan satu persatu.

\section{Daftar Pustaka}

[1] Lidwina A. Masyarakat Asia Tenggara Menonton TV Lebih Lama dari Streaming Video [Internet]. 2021 [cited 2021 May 15]. Available from: https://databoks.katadata.co.id/datapublish/2021/03/31/masyarakat-asia-tenggaramenonton-tv-lebih-lama-dari-streaming-video

[2] Budiono NA. Faktor-faktor Pendorong Orang Menonton Program Berita "Liputan 6" di SCTV (Studi Eksplanatif-Kuantitatif Faktor-Faktor Pendorong Masyarakat Kampung Sudagaran Kelurahan Tegalrejo Yogyakarta Menonton Program Berita Liputan 6 di SCTV) [Internet]. Yogyakarta; 2014. Available from: http://e-journal.uajy.ac.id/id/eprint/6551

[3] Junaidi. Mengenal Teori Kultivasi dalam Ilmu Komunikasi (Cultivation Theory in Communication Science). Simbolika [Internet]. 2018;4(1):42-51. Available from: http://ojs.uma.ac.id/index.php/simbolika\%0AMengenal

[4] Ayu A, Suryawati I. Presentasi Diri News Anchor Pria CNN Indonesia. J Ilm LISKI (Lingkar Stud Komunikasi). 2018;4(2):115-29.

[5] Hasny FA. Strategi Impression Management oleh Beauty Vlogger Kiara Leswara [Internet]. Bandung;2019.Availablefrom: 
106 | Nuril Lutfiah Saaleh, et al.

https://repository.unpad.ac.id/frontdoor/index/index/year/2020/docId/30896

[6] Mulyana D. Metodologi Penelitian Kualitatif: Paradigma Baru Ilmu Komunikasi dan Ilmu Sosial Lainnya. Bandung: PT. Remaja Rosdakarya; 2018. 478 p.

[7] Rakhmat J. Psikologi Komunikasi. Bandung: PT. Remaja Rosdakarya; 2011.

[8] Deahl R. How to Become a TV News Anchor [Internet]. The Balance Careers. 2018 [cited 2021 Mar 16]. Available from: https://www.thebalancecareers.com/tv-news-anchor2316061

[9] Baksin A. Jurnalistik Televisi: Teori dan Praktik. Karyanti R, editor. Bandung: Simbiosa; 2016.

[10] Putra MG, Nasionalita K. ISU LGBT DALAM BINGKAI MEDIA ONLINE (Analisis Framing Robert Entman Pada Pemberitaan Kasus SGRC-UI Terkait ISU LGBT di Indonesia Pada Republika.co.id dan okezone.com). J Ilm Komun Makna. 2018;

[11] Hanurawan F. Metode Penelitian Kualitatif untuk Ilmu Psikologi. 1st ed. Jakarta: Rajawali Press; 2016. 212 p. 